\title{
Rural development as a panacea for rural-urban migration in Nigeria
}

\begin{abstract}
The fact that Nigeria has one of the highest growth rates in the world cannot be overemphasized. Using the census figure of 140 million according to the national population census of 2006 , over $70 \%$ of Nigeria is in the rural areas. A resultant of this growth has led to rapid urbanization and an enormous increase in the population leaving rural areas and now living in urban centers. Demographic, environmental and economic issues become primary areas of concern with the rapid growth of Nigerian urban centers and its attendant effect on rural areas. Policy makers and urban planners are faced with the worries these factors are placing on existing infrastructure and services. While various environmental and socio-economic factors are easily associated with the rapid rural- urban migration trends in Nigeria, it is of utmost importance to identify their impact/implications and developing strategies to combat their effects. This paper therefore ague for rural development as a panacea for rural-urban migration in Nigeria.
\end{abstract}

Volume 2 Issue 5 - 2018

\author{
Kanu Ejikeme Johnson, Ukonze Ifeoma \\ Department of Urban and Regional Planning, University of \\ Nigeria, Nigeria
}

\begin{abstract}
Correspondence: Kanu Ejikeme Johnson, Department of Urban and Regional Planning, University of Nigeria, Nigeria,
\end{abstract} Email ejikeme.kanu@unn.edu.ng

Received: January 15, 2018 | Published: September 19, 2018

\section{Introduction}

The development of rural areas constitutes an important sector in any nation's economy and their rapid development and modernization have gained the attention of policy makers and governments globally. This is due to the fact that a majority of the population lives therein. Hence, the prospects of most developing countries depend largely on it. ${ }^{1}$ Ekpe (2006) defined rural development as the provision of physical infrastructure. The logical basis of this concept is that, the provision of such socio-economic amenities like schools, hospitals, recreational facilities, good road network, electricity and pipe-borne water are capable of transforming the rural communities and eventually making them attractive for habitation.

Nyagba (2009) noted that, the most important sector of the Nigerian population is the rural areas. This, according to Ugwuanyi \& Emmanuel (2013) is because the rural sector is the major source of capital formation for the country and a principal market for domestic and raw materials for industrial processes. Abah (2010) argued that rural area dwellers have been found to engage in primary economic activities that form the foundation for the country's economic development. As it is conspicuously apparent from the foregoing, given the national economy, enhancing the development of the rural sector should be central to government and public administration. Regrettable these rural sectors of Nigeria that are vital to the socioeconomic development of the nation are faced with the problem of retard development. This has been attributed to the top down approach policies of most Nigerian government in the approaches to rural development. Another possible reason for the poor state of the rural areas could be attributed to not continuity of rural development policies and projects by successive government. In this regard, Ajadi (2010) noted that there is usually the absence of sustained, comprehensive and conclusive implementation of rural development policies in Nigeria. The result of the aforementioned is high rate ruralurban migration in Nigeria with its attendant challenges. ${ }^{2}$

\section{Methodology}

This paper adopted the survey design approach in its method of study. The paper is qualitative in nature. It discusses the challenges of rural development, the previous rural development programme, causes and effects of rural-urban migration in Nigerian and rural development and rural -urban migration in Nigeria.

\section{Challenges of rural development}

The challenges threatening rural communities especially in developing countries are numerous and cut across all spheres of life. Most often, rural development policies or programs are discontinued whenever there is a change in government leadership. Most times, a new government abandons the projects and programs of its predecessor even when such programs are appropriate..$^{3-4}$ In this regard, Ajadi (2010) noted that there is usually the absence of sustained, comprehensive and conclusive implementation of rural development policies. A typical example is the abandonment of the Better Life for Rural Women program of former First Lady Mariam Bagangida for the Family Support Programme by the succeeding regime of General Sani Abacha. Some are not well implemented and the targeted population (rural dwellers) hardly benefit as government officials are corrupt and pocket some of the funds released for such programmes. To this end, some of the rural development initiatives are haphazardly implemented as a result of poor supervision and corruption. This is evident in many rural communities with installed water taps that lack water since installation.

Umeabali and Akubuilo (2006) as cited by (Leah et al, 2013) summarized the challenges of rural development to include the following:-

I. High population density.

II. Poor infrastructure.

III. High level of illiteracy.

IV. Extreme poverty.

V. Rural urban migration.

VI. Low social interaction

\section{An appraisal of previous rural development initiatives in Nigeria}

Many governments in Nigeria over the years have made attempts 
at enhancing rural development through various programmes and policies. Its meaningful realization however has remained a mirage. This is clearly seen as there is an apparent lack of basic amenities and the glaring low standard of living conditions among the rural populace (Ugwuanyi and Chukwuemeka, 2013). ${ }^{5}$

Nwuke, (2004) explains that extreme poverty is prevalent among the rural dwellers as about $70 \%$ of the people in Nigeria living below poverty line are domiciled in the rural areas. One major effect of this rural underdevelopment is rural-urban migration, which is fast reducing the active population which constitutes the workforce of the rural areas in Nigeria. In recent times, due to persistent underdevelopment, there has been a noticeably high level of rural-urban migration in search of better standards of living and bigger opportunities for meaningful economic and social activities (Oghoghouje and Jerry-Eze, 2011). This is dysfunctional not only to rural development but retards the overall national development. In view of the foregoing, various Nigerian governments in the past have initiated rural development programmes targeted at the rural sector. ${ }^{6}$ They include:

a) National Accelerated Food Production Programme (NAFPP)

b) River-Basin Development Authority (RBDA)

c) Agricultural Development Programme (ADP)

d) Operation Feed The Nation (OFN)

e) The Green Revolution (GR)

f) Agricultural Credit Guarantee Scheme (ACGS)

g) Directorate For Food, Road And Rural Infrastructure (DFRRI)

h) Better Life For Rural Dwellers

i) National Agricultural Insurance Corporation (NAIC)

j) National Directorate Of Employment (NDE)

k) National Agricultural Land Development Authority (NALDA)

1) National Poverty Eradication Programme (NAPEP)

m) Primary Health Care Programmes (PHCP)

n) National Rural Roads Development Fund (NRRDF)

o) Rural Banking Scheme (RBS)

p) Family Support Programme (FSP)

q) Universal Basic Education (UBE)

r) Expanded Programme On Immunization

s) The Nomadic Education Programme

t) Rural Infrastructure Development Scheme (RIDS)

u) Ferry Transport Schemes (In The Riverine Areas And Lagos)

v) Low-cost Housing Estate Schemes

w) Federal Environmental Protection Agency

x) Flood and Soil Erosion Control Programme.

Many of these programmes were mainly targeted at rural development in an attempt to better the lives of rural dwellers, stimulate and enhance economic growth, as well as get the rural sector to contribute meaningfully to the national economic and social development. These programmes have direct or indirect influence on rural development, with some specific and others generalized. Specific programmes are targeted at agriculture, health, education, housing, transport, and infrastructure while the generalized programmes were put in place to handle general projects and other pressing issues such as unemployment, illiteracy. Such programmes include NDE, DFRRI, Better Life, Family Support Programme, etc.

Many of these specific programmes had some positive effects on rural development although did not last long. Unfortunately, lack of integration of the various rural developmental efforts significantly militated against sustainable rural development. This is largely due to the inability of the rural development institutions to cooperate and ensure their respective initiatives, actions and mandates are coordinated to reinforce and support each other and that their activities are streamlined towards effective realization of government's rural development objectives. ${ }^{7}$

\section{Rural-urban migration in Nigeria, cuases and effects}

Rural-urban migration is one of the most distressing problems facing the Nigerian socio- economic development. A situation where the desire for better employment, business opportunities and education pushes both young and old out of the rural areas to the urban areas. Rural-urban migration represents a phenomenon of unprecedented movement of people from the rural countryside to the urban cities. Historically, migration existed internally across city boundaries to enable excess labour to be taken slowly from the rural areas to provide workforce for industries in the urban areas and therefore aid industrialization and economic growth. However, over time, the rate of rural-urban migration has rapidly outweighed the rate of job creation in developing and underdeveloped countries with overstretched available social and infrastructural facilities in the urban areas.

\section{Cuases of rural-urban migration in Nigeria}

Rural-urban migration may be occasioned by voluntary forces or involuntary forces. Involuntary or forced migration is migration that takes place when the migrant has no choice on whether to move or not. Examples include ethno-religious crises, conflicts and wars, political strife, family and land disputes, conflicts with neighbours etc. Voluntary migration is movement done by choice (Lykke, 2002). Factors responsible for voluntary rural-urban migration include urban job opportunities, better housing conditions, rural land tenure and inheritance patterns, better education opportunities, better health services, extreme poverty etc. Oftentimes, rural dwellers see and hear success stories about people that left the community, moved to cities and are supposedly 'doing well'. This acts as incentives for outmigration especially among youths.

Various studies have been carried out on the causes and consequences of rural-urban migration. While some of these studies related the causes of rural-urban migration to discriminatory government policies in favour of urban development, response to disparities in income, employment and other socio-economic amenities available within the urban and rural areas, with the urban areas being privileged, others related it to spontaneous, emotional, structural, traditional and some other factors. In a cross sectional study of causes and effects of ruralurban migration in Borno State: A case of Maiduguri metropolis, Gimba and Kumshe (2012) found that the major causes of rural-urban migration are search for better education, employment, and business opportunities; while others include: poverty, unemployment, famine, and inadequate social amenities in the rural areas. Study carried out 
by (Adewale, 2006) reveals that various factors could predispose a certain rural population to migration, which might be due to crisis, ethno-religious conflicts and wars etc. Agyemang (2013) summarized the major causes of rural -urban migration in Nigeria. He noted that different motives account for rural-urban migration amongst rural dwellers. These include the following:

1. Socio-cultural issues where people are forced to migrate to avoid numerous social problems at their places of origin.

2. Poor infrastructural development and lack of basic amenities

3. Search for better economic opportunities such as jobs.

4. Accessibility and ease of transportation and communication has also been noted to facilitate rural-urban migration.

5. The extension of road network from major towns to the peripheral urban and rural areas that resulted in the decrease in transportation cost and improved communication systems.

\section{Effects of rural urban migration}

Rural areas are mostly disabled at various levels by inaccessibility, seclusion, underdevelopment, extreme poverty, ignorance, depopulation, hunger and all types of incapacities. Coupled with these is that migration from rural to urban areas leads to a reduction in the number of the rural populace with a negative effect on rural agricultural output and slowed pace of development in the rural areas.

With the exit of youths and young adults from the villages and rural communities, the aged, women and children are left behind to labour on the farms which lead to reduction in agricultural output with its attendant effect on the gross domestic product of the nation, lowered funds for development, income and standard of living of rural inhabitants, underdevelopment, and total desertion of the rural areas.

Constant reduction in rural population over the years will invariably lead to gross rural neglect by government as they tend to concentrate on developing the more obviously populated urban centres. This further reinforces the vicious cycle of gross rural neglect and underdevelopment as reflected in the lack of rural industrialization and poor physical, social and institutional infrastructures. Also, Lykke (2002) opined that rural-urban migration makes the highly educated and most agile people migrate from rural to urban areas, leaving behind the feeble and uneducated people who are not able to combat poverty successfully. This he argues consequentially increases the differences in the standards of living of the rural and urban inhabitants.

Several authors such as Lykke (2002), McCarthy (2004), Adejugbe (2004), Badru (2004), Uma et al (2013), Eliss and Harris (2004), have stated that the incessant drift of the rural populace to the urban areas has led to social, economic, environmental, physical, and other severe problems such as congestion in the urban centres with attendant consequences such as spread of communicable diseases, overstretched social amenities such as electricity, health facilities, educational, recreational facilities, motorable roads, pipe borne water, housing etc.

Other consequences of rural-urban migration includes urban traffic congestion, unemployment, high crime rate such as advance free fraud, political and civil unrests, armed robbery, alcoholism, drug abuse, prostitution, hooliganism, health hazards from pollution; air, water, and noise, inadequate refuse and sewage disposal system, poor drainage system resulting in flooding. Growth of slums leading to shanty settlements, cultural changes, juvenile delinquency and an overall decline in traditional values, are all attendant effects of ruralurban migration.

\section{Rural development and rural-urban development}

Current findings in the field of rural development have led to the conclusion that rural-urban migration could be reduced with the involvement of the rural communities and rural beneficiaries of a rural development project at all stages or phases of the project (Ocheni and Nwankwo, 2012). ${ }^{8}$ The people's contributions in form of ideas, financial and human resources will serve as a motivating factor for them to see to the complete success of the programme and since the local people know and understand their environment and conditions better than the policy formulators and decision makers who operate from outside, it is better to involve them. Again, studies from the developed world where policy makers explore all possible options and adopt inclusive practices in the rural development policies and where appropriate institutional framework are put in place to strengthened and ensure rapid realization of rural developmental goals, the trend in rural-urban migration has been stemmed. It is also instructive to note that in the developed world where government is seen and viewed as continuum, rural development project are not abandonment. Since major finding note that the major causes of rural-urban migration are search for better education, employment, and business opportunities, poverty, unemployment, famine, and inadequate social amenities in the rural areas, it follows therefore that with conscious effort towards rural development, the trend of rural -urban migration will be drastically reduced. Finding reveals that rural development is significant to combating rural-urban migration in Nigeria and indeed it is capable of changing the ways through which we manage the rural areas which will make a difference in governance practice in Nigeria.

\section{Conclusion}

In conclusion, this paper shows that through appropriate rural development programme by government, rural-urban migration can be curtailed. As part of the findings of this paper, the impediments to rural development is majorly the non-commitment to policies initiated by government in Nigeria, while the absence of rural development does facilitate rural-urban migration due to lack of basic social amenities and infrastructures. The findings also revealed that Government needs to do more to stem rural-urban migration. Government must intensify rural development in Nigeria as expected by majority of the rural populace. People in the rural areas have no need to migrate to the urban centers, if basic social amenities and other variables to make them comfortable are provided for in the areas.

\section{Acknowledgments}

None.

\section{Conflict of interest}

Author declares there is no conflict of interest.

\section{References}

1. Adamolekun L. Public Administration: A Nigerian and Comparative Perspective. London; 1983.

2. Adamolekun L. Politics and Administration in Nigeria: Ibadan Spectrum Books. 1993.

3. Anyawu KC. Public Administration in Nigeria: Implications in Development and Sustenance. 1997. 
4. Awa E. Federal Government in Nigeria. University of California Press 1964.

5. Asilo ST. The Place of Infrastructure Development in Nation Building. 1991.

6. Adefolarin AO. Contemporary Issues on Local Government, Rural and Community Development. Abuja: Gapss Think Tank; 2015.
7. Osuala EC. Introduction to Research Methodology. African-Fep Publishers Ltd; 2001.

8. Rodney W. How Europe Underdeveloped Africa. London; 1972.

9. Tadoro A, Smith T. Third World Economic Development. 2007.

10. Rowstow W. The Stages of Economic Growth: A Communist Manifesto Cambridge University Press. 1960. 